\title{
Tingkat Keberhasilan Pelaksanaan Eliminasi Buatan Pada Ternak Sapi Di Kecamatan IV Angkat Candung Kabupaten Agam
}

\author{
Tinda Afriani \\ Jurusan Produksi Ternak Fakultas Peternakan Universitas Andalas, Padang
}

\begin{abstract}
A field survey has been conducted to study the parameter achievements of artificial insemination (AI) by 4 different breeds of cows in IV Angkat Candung sub district of Agam District, West Sumatra. Data collected included conception rate (CR), service per conception $(S / C)$ and calving rate from 496 cows which were divided into 4 offspring breeds: Simmental, Ongol, Charolais and Brahman. Results showed that the achievements of $A I$ in the surveyed area were relatively high. The $C R, S / C$ and Calving rate were found $76.68 \%, 1.30$ and $72.57 \%$, respectively. The most fertile cow was indicated by Ongol
\end{abstract}

Key words: AI, conception rate, service per conception, calving rate.

\section{Pendahuluan}

Upaya meningkatkan produktivitas sapi pejantan melalui penerapan teknologi Inseminasi buatan (IB) khususnya di Kecamatan IV Angkat Candung dipandang sangat tepat karena cara ini diharapkan mampu mengubah peternakan ke arah yang lebih menguntungkan. Melalui Inseminasi Buatan dapat dimasukkan materimateri genetik yang terseleksi yang berasal dari pejantan unggul, sehingga memperbesar populasi dan produksi ternak secara kualitatif dan kuantitatif (Yasin dan Dilaga, 1989).

IB di Indonesia telah dimulai sejak tahun 1952 yang dikembangkan oleh Prof. Borge, Seit seorang ahli berkebangsaan Denmark di Fakultas Kedokteran Hewan dan Lembaga Penelitian Bogor. Di Sumatera Barat dilaksanakan pada tahun 1971 di Kabupaten 50 Kota sebagai pilot proyek. Pada tahun
1975 IB dikembangkan di Kabupaten Agam dan di Kecamatan IV Angkat Candung pada tahun yang sama.

Pada ternak sapi, program IB perkembangannya lebih pesat dari ternak lainnya. Hal ini mungkin karena sistem pemeliharaan yang teratur atau secara intensif serta adanya perhatian baik pemerintah maupun peternak dalam meningkatkan kualitas genetik ternak sapi.

Salah satu alat pengukur keberhasilan suatu pelaksanaan program pengembangan, peningkatan mutu dan populasi ternak sapi yang dilakukan secara IB adalah pengukuran terhadap Conception Rate (CR), Service Perconception (S/C), Calving Rate (Toelihere, 1981).

Efisiensi reproduksi berguna untuk mengevaluasi kegiatan IB yang telah dilaksanakan dan dapat dijadikan sebagai pedoman dalam mencegah atau mengurangi gang- 
guan reproduksi dimasa yang akan datang.

\section{Metoda Penelitian}

Sapi yang digunakan adalah sapi yang di IB dari bulan Januari sampai Desember 2003 sebanyak 496 ekor yang terdiri dari sapi Turunan Simmental 239 ekor, Turunan Limousin 119 ekor, Turunan Brahman 56 ekor, PO 44 ekor, Turunan Charolais 38 ekor. Semen yang digunakan berasal dari sapi Simmental yang diproduksi tahun 2002 pada Balai Inseminasi Biatan (BIB) Tuah Sakato Limbukan Payakumbuh Kabupaten 50 Kota.

Penelitian ini dilakukan dengan metoda survey dan pengambilan data dilakukan secara purposive sampling. Data primer diperoleh dari Inseminator dan data sekunder diperoleh dari Dinas Peternakan Tingkat I Kabupaten Agam.

Variabel yang diukur adalah :

1. Conception Rate yaitu persentase sapi betina yang bunting pada inseminasi pertama.

2. Calving Rate yaitu persentase anak sapi yang lahir hidup dan normal

3. Service Per Conception (S/C) yaitu ditentukan berdasarkan rata-rata jumlah inseminasi yang dibutuhkan oleh seekor sapi betina sampai terjadi kebuntingan.

Data yang diperoleh dianalisa dengan membandingkan $\mathrm{CR}$ dan
Calving Rate ternak sapi yang IB dengan menggunakan analisis statistik Z-test (Sudjana, 1992) dengan rumus :

$\mathrm{z} \frac{\left(x_{1} / n_{1}\right)-\left(x_{2}-n_{2}\right)}{\sqrt{p q\left\{\left(1 / n_{1}\right)+\left(1 / n_{2}\right)\right\}}}$

Dimana :

$\mathrm{x}_{1}=$ Jumlah sapi yang bunting

$\mathrm{x}_{2}=$ Jumlah sapi yang bunting

$\mathrm{n}_{\mathrm{l}}=$ Jumlah sapi yang di IB

$\mathrm{n}_{2}=$ Jumlah sapi yang di IB

$\mathrm{p}=$ Proporsi sapi yang bunting

$\mathrm{q}=$ Proporsi sapi yang bunting

Untuk membandingkan S/C tenak sapi yang di IB digunakan analisis statistik z-test dengan rumus

$$
\begin{aligned}
& \mathrm{S} \overline{\mathrm{x}_{1}}-\overline{\mathrm{x}_{2}}=\sqrt{S^{2} \operatorname{gab}\left(1 / n_{1}+1 / n_{2}\right)} \\
& \mathrm{z}=\frac{\overline{x_{2}}-\overline{x_{1}}}{S \overline{x_{1}}-x_{2}}
\end{aligned}
$$

Dimana :

$\overline{\mathrm{x}_{1}}=$ Rata-rata, Service Per Conception sapi yang di IB

$\overline{x_{1}}=$ Rata-rata Service Per Conception sapi yang di IB

$\mathrm{n}_{1} \quad$ = Jumlah sapi yang bunting

$\mathrm{n}_{2} \quad=$ Jumlah sapi yang bunting

$\mathrm{S} \quad=$ Simpangan baku

\section{Hasil Dan Pembahasan}

\section{Conception Rate (CR).}

Dari hasil penelitian didapatkan Conception Rate (CR) pelaksanaan IB pada ternak sapi di Kecamatan IV Angkat Candung seperti yang terlihat pada Tabel 1. 
Tabel 1. Conception Rate (CR) hasil IB pada Ternak Sapi Di Kecamatan IV Angkat Candung Tahun 2003

\begin{tabular}{lcccc}
\hline \multirow{2}{*}{ Bangsa Sapi } & \multicolumn{3}{c}{ Jumlah Sapi Betina } & \multirow{2}{*}{ CR (\%) } \\
\cline { 2 - 4 } & IB & Bunting IB I & Tidak Bunting & \\
\hline T. Simmental & 239 & 168 & 71 & 70,29 \\
T. Limousin & 119 & 91 & 28 & 76,47 \\
T. Brahman & 56 & 43 & 13 & 76,78 \\
PO & 44 & 37 & 7 & 84,09 \\
T. Chalorais & 38 & 25 & 13 & 65,78 \\
\hline \multicolumn{1}{c}{ CR rata-rata } & & & 76,68 \\
\hline Ket : T = Turunan & & & &
\end{tabular}

Dari Tabel 1 didapatkan bahwa nilai CR sapi yang di inseminasi di Kecamatan IV Angkat Candung tahun 2003 adalah sebesar 76,68\%. Nilai CR ini dapat dikatakan baik sesuai dengan pendapat Toelihere (1985 b) bahwa nilai CR yang baik pada peternakan di Indonesia adalah diatas $65 \%$. Partodiharjo (1978) menyatakan bahwa ada beberapa hal yang mempengaruhi angka konsepsi antara lain kesuburan betina dan waktu inseminasi yang tepat.

Nilai CR pada sapi Peranakan Ongole 84,09 \% adalah tertinggi, diikuti oleh sapi Turunan Brahman $78,76 \%$ sapi Turunan Limousin $76,47 \%$ Turunan Simmental 70,29 $\%$ dan terendah adalah Turunan Chalorais $65,78 \%$. Berdasarkan uji-z terhadap $\mathrm{CR}$ pada masing-masing bangsa sapi menunjukkan perbedaan yang nyata $(\mathrm{P}>0,05)$ antara sapi Peranakan Ongole (PO) dengan Turunan Simmental, Peranakan Ongole dan Turunan Charolais. Hasil berbeda tidak nyata $(\mathrm{P}<0,05)$ antara bangsa sapi yang lain. Hal ini menunjukkan bahwa tingkat kesuburan sapi PO lebih baik dari Turunan Simmental, Turunan Limousin Turunan Brahman, Turunan Chalorais.

Atmadilaga dkk (1974) menyimpulkan bahwa titik berat ketidakberesan kegiatan IB tidak terletak pada kualitas bibit (semen) pejantan, tapi juga pada ketidakterampilan zooteknik peternakan dan keterampilan inseminator, melainkan sebagian besar terletak pada ketidaksuburan ternak-ternak betina itu sendiri. Disamping itu adanya peternak yang mempekerjakan ternaknya setelah inseminasi yang juga dapat menurunkan angka CR yang diperoleh.

Nilai CR yang tinggi juga dipengaruhi oleh pada saat sapi betina pertama kali dikawinkan. Dimana sapi pertama dikawinkan pada umur 18-24 bulan ini sesuai dengan pendapat Ensminger (1960) bahwa walaupun dewasa kelamin telah tercapai pada umur 8-12 bulan, namun perkawinan ditunda dulu, hal ini bertujuan untuk menghindari halhal yang tidak menguntungkan serta menurunnya angka konsepsi, angka kelahiran rendah, gangguan pertumbuhan induk dan panjangnya Calving Interval. Tingginya angka CR juga dipengaruhi oleh panjangnya jarak kawin sesudah sapi beranak. Sasroamidjojo dan Soeradji (1978) menegaskan bahwa sesuai dengan tingkat pertumbuhannya, maka ternak sapi dikawinkan pertama kali umut 2-2,5 tahun disamping umur kawin pertama, maka jarak waktu melahirkan dengan 
perkawinan kembali sesudah melahirkan juga besar pengaruhya.

\section{Calving Rate.}

Dari hasil penelitian didapatkan angka Calving Rate dari pelaksanaan IB di Kecamatan IV Angkat Candung tahun 2003 seperti terlihat pada Tabel 2.

Dari Tabel 2 dapat dilihat angka Calving Rate pada ternak sapi yang di IB di Kecamatan IV Angkat Candung tahun 2003 adalah 72,57\%. Angka kelahiran yang didapatkan cukup baik. Toelihere $(1985$ b) menyatakan nilai Calving Rate dapat mencapai $62 \%$ untuk satu kali Inseminasi.

Nilai Calving Rate masingmasing bangsa sapi adalah PO 79,54 $\%$ Turunan Brahman 76,68\%, Turunan Limousin 74,78 \% Turunan Simmental $68,61 \%$ dan Turunan

Tabel 2. Angka Calving Rate Hasil IB pada Sapi di Kecamatan IV Angkat Candung Tahun 2003

\begin{tabular}{lcccc}
\hline \multirow{2}{*}{ Bangsa Sapi } & JB & Lahir IB I & Tidak Lahir & $\begin{array}{c}\text { Calving } \\
\text { Rate } \\
\text { CR (\%) }\end{array}$ \\
\hline T. Simmental & 239 & 168 & 75 & 68,61 \\
T. Limousin & 119 & 89 & 30 & 74,78 \\
T. Brahman & 56 & 43 & 13 & 76,78 \\
PO & 44 & 35 & 9 & 79,54 \\
T. Chalorais & 38 & 24 & 14 & 63,15 \\
\hline CR rata-rata & & & & 72,57 \\
\hline
\end{tabular}

Ket : $\mathrm{T}=$ Turunan

Tabel 3. Angka Service Per Conception (S/C) Hasil IB pada Sapi di Kecamatan IV Angkat Candung Tahun 2003

\begin{tabular}{|c|c|c|c|c|c|c|}
\hline \multirow[t]{2}{*}{ Bangsa Sapi } & \multirow{2}{*}{$\begin{array}{c}\text { Jumlah } \\
\text { Betina } \\
\text { IB }\end{array}$} & \multicolumn{3}{|c|}{ Jumlah Sapi Betina } & \multirow{2}{*}{$\begin{array}{l}\text { Jumlah } \\
\text { Service }\end{array}$} & \multirow[b]{2}{*}{$\mathrm{S} / \mathrm{C}$} \\
\hline & & 1 & 2 & 3 & & \\
\hline T. Simmental & 239 & 168 & 57 & 14 & 324 & 1,35 \\
\hline T. Limousin & 119 & 91 & 20 & 8 & 155 & 1,3 \\
\hline T. Brahman & 56 & 43 & 12 & 1 & 70 & 1,25 \\
\hline $\mathrm{PO}$ & 44 & 37 & 5 & 2 & 53 & 1,2 \\
\hline T. Chalorais & 38 & 25 & 10 & 3 & 54 & 1,42 \\
\hline $\mathrm{S} / \mathrm{C}$ rata-rata & & & & & & 1,3 \\
\hline
\end{tabular}




\section{Service Per Conception.}

Dari hasil penelitian angka S/C dari pelaksanaan IB di Kecamatan IV Angkat Candung tahun 2003 sebagaimana yang terlihat pada Tabel 3 berikut.

Dari Tabel 3 dapat diketahui bahwa S/C sapi yang di inseminasi di Kecamatan IV Angkat Candung tahun 2003 sudah baik. Menurut Toelihere $(1985$ b) nilai $\mathrm{S} / \mathrm{C}$ yang baik adalah 1,0 - 1,6, makin rendah nilai $\mathrm{S} / \mathrm{C}$ makin tinggi kesuburan hewan-hewan betina dalam kelompok tersebut, sedangkan makin tinggi nilai $\mathrm{S} / \mathrm{C}$ makin rendah kesuburan hewan-hewan betina dalam keoompok tersebut. Nilai S/C pada sapi PO 1,20 dan Turunan Brahman 1,25 lebih baik dari sapi Turunan Limousin 1,30, Turunan Simmental 1,35 dan. Turunan Charolais 1,42 . Hal ini menunjukkan bahwa tingkat kesuburan sapi PO dan Turunan Brahman lebih baik dari sapi Turunan Limousin, Turunan Simmental dan Turunan Chalorais. Berdasarkan uji z terhadap S/C pada masing-masing bangsa sapi menunjukkan hasil berbeda dan tidak nyata $(\mathrm{P}<0,05)$ pada semua bangsa sapi.

Nilai S/C yang tinggi juga tidak terlepas dari keterampilan inseminator yang berpengalaman sesuai dengan pendapat Soeharsono dan Paggi (1978) bahwa untuk memperkecil S/C diperlukan keterampilan inseminator, keterampilan peternak dan mengelola ternaknya terutama dalam proses reproduksi.

\section{Kesimpulan}

\begin{tabular}{|c|c|c|}
\hline Tingkat & keberha & dari \\
\hline & pada & sapi \\
\hline urunan & Brahman, & Turunan \\
\hline Limousin, & Turunan & Simmental, \\
\hline runan & Charolais & \\
\hline
\end{tabular}

menggunakan semen sapi Simmental yang berasal dari Balai Inseminasi Buatan (BIB) Tuah Sakato di Kecamatan IV Angkat Candung adalah tinggi. Dari jumlah akseptor 496 ekor didapat nilai Conception Rate (CR) 76,68 \%, Service Per Conception (S/C) 1,30 dan Calving Rate $72,57 \%$ dari nilai $C R, S / C$ dan Calving Rate tingkat kesuburan sapi PO lebih baik dibandingkan sapi Turunan Limousin, Turunan Simmental, Turunan Brahman dan Turunan Charolais.

\section{Daftar Pustaka}

Atmadilaga, D. S, Djojosoedarmo, M. A. Dasuki, M. R. Toelihere, dan A. adnan. 1974. Evaluasi Hasil Inseminasi Buatan Pada Ternak Sapi Di Jawa 19721974. Ditjen Peternakan. Jakarta

Badan Pusat Statistik. 2003. Kecamatan IV Angkat Candung Dalam Angka. Kabupaten Agam.

Ensminger, M. E. 1960. Management of Beef Catte. 3 rd Ed. The Interest Printarsi and Publisher, Inc. Penville.Llions.

Partodiharjo, S. 1992. Ilmu Reproduksi Hewan. Cetakan ke-3. Mutiara Sumber Widya. Jakarta

Soeharsono dan Paggi. 1978. Performance Sapi Perah di Indonesia. Seminar Produktifitas Ternak Sapi Program Penelitian. Institut Pertanian Bogor. Bogor. 
Sosroamidjojo dan Soeradji, 1980.

1985 b. Inseminasi

Peternakan Umum. Cetakan

III. CV. Yasaguna. Jakarta Buatan Pada Ternak. Penerbit Angkasa. Bandung

Sudjana, M. A. 1992. Metode Statistika. Edisi ke-5. Tarsito. Bandung

Toelihere, M. R. 1981. Fisiologi Reproduksi Pada Ternak. Penerbit Angkasa. Bandung

Alamat korespondensi: Ir. Tinda Afriani,MP Jurusan Produksi Ternak, Fakultas Peternakan Universitas Andalas, Kampus Limau Manis, Padang Telp. 0751-74208 Fax: 0751-71464.

Diterima: 15 Maret 2007, Disetujui: 21 Mei 2007 